\title{
Turizm Yöneticilerinin Ekoturizm Algısının AHP Yöntemi ile Belirlenmesi: Giresun İli Örneği
}

$\ddot{O} \mathbf{z}$

\author{
Melek Turan* \\ Hakan Akyurt**
}

Çalışmanın amacı, özellikle Doğu Karadeniz Bölgesinde önemli bir turizm çeşidi haline gelen ekoturizm kavramının turizm yöneticilerinin algılarındaki yerinin belirlenmesidir. Turizm yöneticilerinin ekoturizme bakış açılarının ortaya konması ve tutumlarının tespiti hedeflenmektedir. Birçok farklı turizm çeşidini bünyesinde barındıran ekoturizm faaliyetlerinin, mevcut ve geleceğe yönelik olarak, Giresun turizmine katkısının durumu belirlenmeye çalışılmıştır. Bu kapsamda, çok kriterli karar verme yöntemlerinden biri olan Analitik Hiyerarşi Prosesi (AHP) yöntemi kullanılarak, Giresun ilinde otel ve seyahat yöneticileri, İl Kültür Turizm Müdürlüğü yöneticileri, turizm alanında çalışan sivil toplum kuruluşları yöneticileri ve turizm eğitimi almış alanında uzman akademisyenler ile anket yapılmıștır. AHP yöntemine uygun olarak hazırlanan anket formunda, doğal şartlar, ulaşım, güvenlik, fiyat, iklim, yayla turizmi ve konaklama tesisleri kriterleri kullanılmıştır. Ayrıca, SPSS analizi ile yöneticilerin demografik bulgularına yönelik sonuçlar elde edilmiştir. Toplam 10 turizm yöneticisi ile yüz yüze şekilde anketler uygulanmış ve sonuçlar analiz edilmiştir. Çalışma sonucunda, ekoturizm destinasyonlarında gerçekleştirilen turizm faaliyetlerini etkileyen kriterlerin seçimine yönelik öncelik sıralanması en önem verilenden az önem verilene doğru sırayla güvenlik, ulaşım, fiyat, iklim, yayla turizmi, konaklama tesisleri ve doğal şartlar olarak belirlenmiştir. Turizm yöneticileri tarafından ekoturizme etki eden en önemli kriterin güvenlik olduğu ifade edilmektedir.

Anahtar Kelimeler: Turizm, Ekoturizm, Turizm Yöneticileri, Giresun ili Turizmi, AHP Yöntemi.

\section{Determining the Ecotourism Perception of Tourism Managers by AHP Method: The Case of Giresun Province}

\begin{abstract}
The aim of the study is to determine the place of the concept of ecotourism in the perceptions of tourism managers which has become an important type of tourism especially in the Eastern Black Sea Region. It is aimed to determine their attitudes and to reveal the perspectives of tourism managers on ecotourism. It has been tried to determine the current and future contribution of ecotourism activities, which include many different types of tourism, to Giresun tourism. In this context, using the Analytical Hierarchy Process (AHP) method, which is one of the multi-criteria decision-making methods, a survey was conducted with hotel and travel managers in Giresun, the managers of the Provincial Directorate of Culture and Tourism, the managers of non-governmental organizations working in the field of tourism and academicians who are experts in the field of tourism education. In the questionnaire prepared in accordance with the AHP method that the criteria of natural conditions, transportation, safety, price, climate, highland tourism and accommodation facilities were used. In addition, the results of the demographic finding s of the managers were obtained by SPSS analysis. The results were analyzed and conducted total of 10 tourism managers with face-to-face surveys. As a result of the study, the order of priority for the selection of the criteria affecting the tourism activities carried out in ecotourism destinations has been determined as safety, transportation, price, climate, highland tourism, accommodation facilities and natural conditions, in order from the most important to the least important. It is stated by tourism managers that the most important criterion affecting ecotourism is safety.
\end{abstract}

Keywords: Tourism, Ecotourism, Tourism Managers, Giresun Province Tourism, AHP Method.

Geliş/Received: 14.09 .2021

Kabul/Accepted: 30.12 .2021

- Bu çalışma için Giresun Üniversitesi Rektörlüğü, Sosyal Bilimler Fen ve Mühendislik Bilimleri Araștırmaları Etik Kurulu'ndan 07 Nisan 2021 tarih ve 09/29 sayı ile etik kurul izni alınmıştır.

\footnotetext{
* Yüksek Lisans Öğrencisi, Giresun Üniversitesi Sosyal Bilimler Enstitüsü, Ekoturizm Rehberliği Ana Bilim Dall, mlkatilgan@haotmail.com, ORCID ID:0000-0002-7089-800X

** Doç. Dr., Giresun Üniversitesi Bulancak KK Uygulamalı Bilimler Yüksekokulu, Turizm İşletmeciliği Bölümü, hakan.akyurt@giresun.edu.tr, ORCID ID: 0000-0002-6522-684X

(Makale Türü: Araștırma Makalesi)
} 


\section{Giriş}

Değişen hayat koşulları insanların yaşam biçimlerine de etki etmekte olup, bu durum turizm davranışlarına da yansımaktadır. Özellikle salgın hastalıkların artması ile turistlerin beklentilerinde ve ihtiyaçlarında farklılıklar ortaya çıkmaya başlamıştır. Bu nedenle, turizm ürünlerinin çeşitlendirilmesi yoluna gidilmiş ve turizm yöneticileri uzun dönemlerde daha fazla turistik talep yaratacak çözümler bulmaya yönlendirmiştir. Bu doğrultuda, son yıllarda yaşanan çevresel ve sağlkla ilgili olaylara tepkisel olarak gelişen hassasiyet, insanların turizm tercihlerini doğaya faydalı olmak ve kalabalıklardan uzaklaşma arzusu ile sürdürülebilir turizm faaliyetlerine yöneltmesine neden olmuştur. $\mathrm{Bu}$ turizm çeşitlerinden son zamanlarda en çok tercih edilenlerinden biri de ekoturizm faaliyetleridir.

Ekoturizmin temel hedefi sürdürülebilir bir bölgesel gelişimin sağlanmasıdır. $\mathrm{Bu}$ durum, ekoturizm ilkelerinin sürdürülebilir şekilde uygulanması ile gerçekleşebilir. Maalesef ülkemizde turizm alanlarının planlanmasında eksiklikler bulunmaktadır. Ülkemizde turizmin doğal kaynaklara doğru yönelişi, doğal kaynakların da birçoğunun kırsal mecralarda bulunması, kırsal mecralardaki arazi kullanımını değiştirmektedir. Bu yüzden kırsal mecraları çekicilik özelliğini yitirmemesi için, kısa süre içerisinde kırsal turizm faktörlerini içerisinde bulunduran ekoturizme yönelmek gerekmektedir (Doğaner, 2001: 1).

Ekoturizm faaliyetlerinde öncelik, çekici doğal alanların, flora ve faunanın korunmasıdır. Bu nedenle, doğanın korunmasını sağlamak, yıkıcı olumsuz etkilerden kurtulmak ve yöre halkının ekoturizmden para kazanmasına yardımcı olmak amacıyla, korunan alanlara yönelik olarak tehditleri azaltmak gerekmektedir (Bhattacharya, Chowdhury ve Sarkar, 2011: 1905). Ekoturizm, özellikle yeni turizm destinasyonlarında bölgesel gelişimi, çevrenin korunmasını ve istihdam olanaklarının artmasını sağlayacak nitelikte bir turizm ürünü olarak kabul edilen, doğa temelli turizm çeşidi olarak günümüzde önemini daha da arttırmış bulunmaktadır.

Bu kapsamda, Doğu Karadeniz Bölgesi, ekoturizm alanlarının fazlalığı ile dikkat çeken bir bölgedir. Ekoturizm faaliyetlerinin gerçekleştirilebileceği alanların mevcudiyeti nedeni ile son yıllarda bölgedeki illerde yatırımlar ve turistik hareketler artmaya başlamıştır. Giresun ili ekoturizm faaliyetlerinin yapılabileceği birçok destinasyona sahip önemli bir il olarak karşımıza çıkmaktadır. Ekoturizm faaliyetlerinin etkin bir şekilde yönetilebilmesi ve sürdürülebilir bir yapıya kavuşturulabilmesi için turizmde rol alan ve de çalışan yöneticilerin ekoturizm algılarının belirlenmesi önem arz etmektedir.

Turizm yöneticilerinin ekoturizm kavramı konusunda bilinç düzeyleri ve algılamaları gelecekte bölgedeki ekoturizm faaliyetlerine yön vereceğinden, ekoturizme etki eden kriterler hakkındaki görüşlerinin tespit edilmesi gerekmektedir. $\mathrm{Bu}$ bağlamda, çalışmada çok kriterli karar verme yöntemlerinden biri olan ve alanında uzman kişiler ile yapılma zorunluluğu olan Analitik Hiyerarşi 
Yöntemi kullanılmıştır. Ekoturizme etki eden temel kriterlerin hangilerinin ne derece önemli olduğu, Giresun ekoturizmine bakış açısını ortaya koyacak olması nedeni ile gelecekteki çalışmalara ve de yatırımlara yol gösterecek nitelikte olacaktır. Ayrıca, ekoturizm yöneticilerinin fikir ve görüşleri doğrultusunda elde edilecek bilgilerin, gelecekteki akademik çalışmalara yol göstermesi mümkün olacaktır. Ekoturizm üzerinde etkili olan kriterlerin her bölge için farklı olabileceği düşünüldüğünde, çalışmanın Giresun ili ve benzer Doğu Karadeniz ekoturizm destinasyonları için önemli bir bilgi kaynağı niteliğinde olması beklenmektedir.

\section{Literatür Taraması}

Ekoturizm kavramı son yıllarda artan önemi ile turizm sektörü içerisinde önemli bir yer edinen kavram haline gelmiştir. Ekoturizm konusunda ülke yatırımları artmış ve turistik talep yaratacak faaliyetler ortaya konmaya başlamıştır. Ekoturizm kavramının turistik talebe etkisi nedeni ile bu alanda lisans ve lisansüstü seviyede eğitimlerde artmıştır. Dünya genelinde artan önemi ile ekoturizm, turizm alanında geliştirilmesi ve üzerinde durulması gereken bir alan olarak karşımıza çıkmaktadır. $\mathrm{Bu}$ kapsamda, ekoturizmin daha iyi anlaşılması amacıyla kısa bir tanımını yapmak gerekirse, 1983 yılında Meksikalı bir çevreci olan "Hector Ceballo Lascurain" tarafindan üretilmiş ve bozulmamış alanlar ile doğaya dayalı seyahatler olarak ifade edilmiştir (Farrell ve Runyan, 2001; Bunruamkaew ve Murayama, 2011

Ekoturizmde öncelik, çekici doğal manzaraların ve zengin flora ve faunanın korunmasıdır. $\mathrm{Bu}$ nedenle, doğanın korunmasını sağlamak, yıkıcı olumsuz etkilerden kurtulmak ve yöre halkının ekoturizmden para kazanmasına yardımcı olmak amacıyla, korunan alanlara yönelik olarak tehditleri azaltmak gerekmektedir (Butarbutar ve Soemarno, 2013: 99). Bununla birlikte, Wood (2002) ekoturizmi yedi genel amaç ile açıklamaktadır (Wood, 2002: 10).

Biyo-çeşitliliğgin korunmasına katkı sağlar,

Yerel halkın refahını sürdürmesine katkı sağlar,

Tecrübe deneyimi içerir,

Turistler ve turizm endüstrisi konusunda sorumlu eylemleri içerir,

Öncelikle küçük ölçekli işletmeler tarafından küçük gruplara teslim edilir,

Yenilenemeyen kaynakların mümkün olan en düşük tüketimini gerektirir,

Kırsal kesimdeki insanlar için mülkiyet ve iş fırsatlarını vurgulamaktadır.

Ekoturizm sektörünün varoluşu, tabiatın ve tabiatı kullanacak insanlara bağlı olarak gelişmektedir (Erdoğan, 2013: 111). Ekoturizm, karşı1lığında biyolojik çeşitliliğin yerel topluma ekonomik teşvikler sağladığı bölgenin ekolojisinin ve biyolojik çeşitliliğinin korunması için yerel toplumu gönüllü hale getirmeye yardımcı olmaktadır. Turizm ve turizm endüstrisi adına yapılan eylemler, küçük ve orta ölçekli turizm işletmelerini teşvik etmek, mümkün olan en düşük doğal kaynak tüketimini gerekli kılmak; özellikle kırsal kesimde yaşayanlar için yerel katılımı, mülkiyeti ve iş firsatlarını sunmakta ve hepsinden önemlisi öğrenme deneyimlerini içermektedir (Kaypak, 2012: 17). 
Ekoturizm bozulan ekolojik dengenin tekrar düzenlenmesine yardımcı olmaktadır. Ekoturizm aktivitelerini dünyaya yaymak, yaşatmak için geçmişten yapılan hataları yapmamak ve gelecekte problemleri çözmek çok önemlidir (Doğan, 2011: 17).

Bölgelerarası dengesizliği azaltmak, ekonomik etkinliklerin arttırmak, ekonomik geliri düşük olmasından kaynaklı göçlerin minimuma indirmek, sosyal barış ile birlikteliği sağlamak ve manevi doğal zenginliği koruyabilmek amaçlı olarak, ekoturizmin doğru kullanılması gerekmektedir (Bhattacharya, Chowdhury ve Sarkar, 2011: 1910). Alternatif turizm ürünü olan ekoturizmin çeşitlendirilmesi için yapılan çalışmaların, turizm endüstrilerinin karının artması için değil, temel amaç doğal alanlardaki yaşamın sürdürülebilirliğinin sağlanması olmak zorundadır. Bu durumun oluşması için yerel halk ile iç ve dış paydaşların birlikte planlama ve koordinasyon yaparak, uzun vadeli bir çalışma içinde olması önem arz etmektedir (Erdoğan, 2003: 106).

Ekoturizm, az gelişmiş ülkelerde ekonomik kalkınmayı teşvik eden bir mekanizma olarak görülmektedir (Ayotte, 2009: 23). Bu nedenle, ekoturizm faaliyetlerinin önemi artmakta ve sürdürülebilir bir ekoturizm anlayışının ülke geneline yayılması gerekmektedir. Ekoturizm, ülke genelinde turizmden elde edilen ekonomik payın dağılımında önemli bir rol oynamaktadır. Yoğun ve çok bilinen turistik destinasyonlar dışındaki destinasyonların hem tanıtılmasında hem alt yapı yatırımlarının arttırılmasında hem de yerel halkın gelir elde etmesinde önemli bir turizm çeşidi olarak görülmektedir. Ekoturizm alanında yapılacak olan yatırımların diğer bir özelliği de doğanın sürekli olarak korunmasına yönelik olarak yapılacak olan çalışmalar olarak ifade edilebilmektedir. Yerel halkın doğaya karşı bakış açısının olumlu olarak değiştirilmesinde ve turizmden gelir elde edilebileceğinin ögretilmesinde, ekoturizm faaliyetlerinin önemli bir etkisi olmaktadır.

Ekoturizmin ekonomik, çevresel ve sosyo-kültürel etkileri genel olarak literatürde yer edinmektedir. Bu kapsamda, ekoturizmin kazandıracağı olumlu ekonomik etkileri aşağıdaki maddelerde özetlemek mümkündür (Yücel, 2002: 3; Tisdell, 2003: 91):

Eko turistlerden sağlanan gelir ekoturizm bölgesine döviz girişi sağlar,

Bölgede yaşayan halk için istihdam olanakları ve gelir sağlar,

Rehberler, yöneticiler ve araştırmacılar için de doğrudan istihdam olanağı sağlar,

Ulaştırma, iletişim, sağlık gibi bölgenin altyapı hizmetlerini geliştirir,

Ekoturizm bölgedeki yerel ürünlere olan talebi artırır,

Az gelişmiş bölgelerde kırsal kesimlerde ekoturizm yaratacağı yatırımlar ve iş imkânları bölgede yaşayan halk için büyük önem taşımaktadır,

Ekoturizm operasyonlarında doğrudan kazançlar ve park giriş ücretleri, yerel sanat ve el sanatları, restoranlar, oteller, barlar ve bu işlemlerden elde edilen vergilerden dolaylı kazançlar sağlamaktadır, Tarımın aktif olmadığ bölgelerde yerel ekonomiyi hareketlendirir, 
Bölgenin tanıtım ve alt yapı maliyetlerinin azalmasına yardımcı olmaktadır.

Ekoturizmin olumlu etkileri olacağı gibi bazı olumsuz etkilerinden de bahsetmem mümkündür. Ekonomik anlamda bir bölgeye getirebileceği olumsuz ekonomik etkileri aşağıdaki gibi kısaca ifade etmek mümkündür (Tisdell, 2003, 91; Kuter ve Ünal, 2009: 153; Y1lmaz, 2015: 166;):

Bölgedeki fiyat artışı (Özellikle yoğun sezonlarda veya sık ziyaret edilen bölgelerde işletmeler tarafından kaynakların aşırı tüketilmesi sonucu arazi fiyatların arışına neden olmaktadır),

Ekoturizmin bir bölgeye yerleştirilmesi uzun süre alacağından yıl boyu düzenli istihdam ve gelir sağlayamamaktadır,

Yaban hayatının korunması sağlanırken, yabani hayatın bölgedeki diğer unsurlarına da zararı olabilmektedir,

Bölgedeki turizm tesislerinin kaynakları aşırı tüketmeleri, elektrik ve su gibi enerji kaynaklarının kesintilerine dahi yol açacak şekilde fiyat artışına sebep olabilir,

Ekoturizm operatörleri yerel işverenlere adil ücret ödememektedir,

Yoğun turizm bölgelerine göre çalışanların ücretleri daha az olabilmekte ve bu durun nitelikli personelin sürekli olarak ekoturizm destinasyonlarında kalmalarına engel olabilmektedir (Akyurt, 2019: $358)$.

Çevresel unsurlar turizm açısından en önemli etkenler olarak ifade edilmektedir. Çevresel bilinç düzeyi ile hareket edilmediği takdirde, turizmin geleceğinin çok parlak olma ihtimali düşmektedir. Çevresel unsurları önemsemeyen ve korumayı hedef edinmeyen turizm anlayışı, turistik talebin gelecek yıllara dağılımında olumsuz sonuçlar ile karşılaşmasına yol açacaktır. Bu nedenle, ekoturizmin temel amacı içerisinde çevresel unsurların korunması ve geliştirilmesi bulunmaktadır. Doğa temelli bir turizm çeşidi olması nedeniyle, ekoturizm faaliyetlerinin çevresel yapıya zarar vermeyecek nitelikte planlanması ve koordine edilmesi gerekmektedir.

Çevresel bozulma, manzaraların yok edilmesini, bitki örtüsü topluluklarının yok edilmesini, vahşi yaşamı, mercan resiflerini ve çöp yığınlarının ortaya çıkmasını içermektedir. Olumsuz turizm yönetim planlarının, çevresel kapasiteye dikkat edilmemesinin ve yerel toplulukların ve turistlerin doğal çevrenin korunmasında bilgi ve de farkındalık eksikliğinin bir sonucu olarak başka olumsuz etkiler de ortaya çıkabilmektedir. Fiziksel, kimyasal ve biyolojik yönler üzerindeki olumsuz sonuçlara neden olmaktadır. Aşırı fazla ziyaret sıklığı nedeniyle toprak erozyonu, doğal peyzajdaki değişiklikler nedeniyle bitki örtüsünün tahrip edilmesi, artan atık hacmi ve motorlu taşıtlardan kaynaklanan gürültü kirliliğine neden olmaktadır (Butarbutar ve Soemarno, 2013: 101).

Ekoturizmin diğer bir etkisi de toplumlar üzerindeki sosyo-kültürel etkilerdir. Olumlu sosyokültürel etkileri arasında geleneklerin ve değerlerin güçlendirilmesi, etkili toplum hizmetleri, artan gönüllülüğü, gelişmiş bölgesel kimliği ve toplum katılımıdır. Ayrıca öğrenme, farkındalık, takdir ve aile bağını içermektedir. Daha sıkı bir etnik kimlik duygusu, empati duygusunun gelişmesi, hoşgörü ve daha güçlü kültürel kimlik sağlamaktadır. Ekoturizmin diğer sosyo-kültürel faydaları ise uyum, fikir alışverişi 
ve bir destinasyonun kültürü hakkında bilgi ve de birikimleri arttırmaktır. Ekoturizm de en büyük üç fayda; artan koruma bilinci, ekosistem hizmetlerinin sağlanması ve kültürel kimliğin korunmasıdır (Das ve Chatterjee, 2015: 5).

Ekoturizme etki eden unsurlar bölgelere ve ülkelere göre değişiklik gösterebilmektedir. Ancak, temel olarak ekoturizm üzerinde etkili olan kriterlerin benzer nitelikte olduğu, sadece bu kriterlerin önem derecesinin bölgesel özelliklere, turist profiline ve yerel halkın durumuna göre değişiklikler gösterdiği bilinmektedir. Ekoturizm kriterleri, bölgedeki kamu turizm yönetimlerinin, turizm tesislerinin ve turizm aracı kuruluşlarının yönlendirmeleri ile şekil almakla birlikte, turistlerin istek ve ihtiyaçlarına göre de belirlenmektedir. Bu kapsamda, ekoturizm destinasyonlarını etkileyecek olan kriterlerin neler olduğunun önem derecesine göre belirlenmesi önemli bir husus olarak dikkat çekmektedir.

Literatürde ekoturizm faaliyetleri gerçekleştirirken etki eden faktörler genel olarak coğrafi konumu, iklim, fiyat, ulaşım, altyapı, güvenlik, konaklama tesisleri, mesafe, kültürel ve tarihi kaynaklar, sosyo-kültürel yapı, doğal manzaralar, tabiat parkları gibi faktörler tarafindan etkilendiği belirtilmektedir (Ilgaz ve Kozak, 2019: 497). Ayrıca, ekoturizm yapılan bölgelerde yerel halkın ekoturizme katılımı olumlu yönde olduğu takdirde gelişim göstermekte, eğer katılımı zayıf olursa, olumsuz yönde etkilenme olduğu görülmektedir (Işık ve Çalkın, 2016: 20). Bu bağlamda, yerel halkın tutum ve davranışlarının belirlenmesi konusunda ekoturizm alanında çalışmakta olan bölgedeki turizm yöneticilerinin fikir ve görüşleri önem kazanmaktadır.

Genel olarak, ekoturizm alanında çalışmanın konusu ile ilgili benzer literatür çalışmaları ise aşağıdaki gibi özetlenebilir.

Bunruamkaewa ve Murayama (2011), ekoturizm alanları için AHP yöntemi kullanarak uygunluk denetimi konulu çalışma yapmıştır. Otel yöneticilerine yapmış oldukları anketlerde, 9 kriter üzerinde çalışmışlardır. Bu araştırma, yöntem bakımından mevcut çalışma ile benzerdir. Uygulama evreni ve kriterler bakımından farklılıklar göstermektedir.

Chan (2013), tarafindan yeşil pazarlama ve ekoturizm üzerinde otel yöneticilerinin algısına yönelik olarak çalışma yapılmıştır. Çalışmada, ekoturizm turizm stratejilerine yönelik olarak otel yöneticilerinin görüşleri alınmıştır. Yöntem ve konu bütünlüğü açısından farklı bir çalışma yapılmıştır.

Akbulut, Atmış ve Günşen (2015), Küre dağları ekoturizm destinasyonlarına yönelik olarak kamu yöneticileri, özel sektör, sivil toplum örgütleri ve muhtarlar odaklı çalışma yapmışlardır. Çalışmada, çalışma yapılan grupların milli parklar üzerindeki algılamaları üzerinde durulmuştur. Ekoturizmin algılanması bakımından benzerlik olsa da, yöntem ve hedef kitle bakımından önemli farkl11ıklar bulunmaktadır. 
Ahmadova ve Akova (2016), tarafından ekoturizm çiftlikleri üzerinde turizm işletmelerine yönelik çalışma yapılmıştır. Çalışmanın konusu ekoturizm çiftlikleri ile sınırlıdır ve yöntem bakımından farkl11ık göstermektedir.

Gündüz ve Dönmez (2018), Karabük üniversitesi personelinin ekoturizm algısını ölçmeye yönelik olarak çalışma yapmış, çalışma sonucunda çevre algısının önemli olduğu ortaya çıkmıştır. Demografik duruma göre SPSS analizi uygulanmış, çevre bilincine yönelik olarak yaş gruplarına göre sonuçlar verilmiştir. Çalışma, yöntem ve konunun incelenmesi bakımından farklılık göstermektedir.

Ünlü ve Erbaş (2021), yapmış oldukları çalışmalarında Trabzon'daki otel yöneticilerinin ekoturizm algılamalarını tespit etmeye yönelik çalışma yapmışlardır. Swot analizinin uygulandığı çalışmada, ekoturizmin Trabzon otel yöneticileri açısından en güçlü yanının eşsiz bir doğaya ve kültürel birikime sahip olması sonucu ortaya çıkmış, en zayıf yanının ise ekoturizm bilincinin yerel halk arasında tam olarak yerleşmemesi olduğu belirtilmiştir. Yapılmış olan çalışma yöntem ve sonuç bakımından farkl11ık göstermektedir.

Ekoturizm üzerinde yapılan makale ve tezler incelediğinde, genel olarak ekoturizm üzerinde algılamalara yönelik olarak, turistleri, yerel halkı ve bölge yerel yöneticilerini konu alan çalışmalar olduğu görülmektedir. Ekoturizm konusunda algılamaların turist ve yerel halk kapsamında ele alındığ1 ve analiz yönteminin ise genel olarak SPSS analizi ya da SWOT analizi ile değerlendirmeler yapıldığ görülmektedir. $\mathrm{Bu}$ çalışmanın konusu olan ekoturizmin yerel turizm yöneticileri tarafından algılanmasına yönelik olarak çalışma tam kapsamlı olarak bulunamamıştır. Ayrıca çalışmada kullanılan AHP yöntemi ile turizm yöneticilerinin algılanmasına yönelik olarak yapılmış olan bir çalışmaya rastlanamamıştır.

\section{Araştırmanın Yöntemi}

\section{Araștırmanın Amacı}

Araştırmanın genel amacı, ekoturizm destinasyonlarında etkili olan kriterlerin turizm yöneticilerinin bakış açıları ile önem derecesine göre ortaya konulmasıdır. Alt amaç olarak ise, Giresun ili ekoturizm destinasyonlarına etki eden unsurlardan hangilerinin daha önemli olduğunun, Giresun'da çalışmakta olan turizm yöneticileri ve akademisyenlerin fikirleri doğrultusunda ortaya koymaktır. Giresun ili turizmine yön veren turizm yöneticilerinin algılarının tespiti, Giresun ekoturizminin şekillendirilmesi bakımından önem arz etmektedir. Elde edilen veriler ile Giresun ili ekoturizm destinasyonlarında hangi kriterlerin daha önem verilerek, üzerinde çalışılması gerektiği sonucu ortaya çıkacaktır. Böylece, uzun vadede ekoturizm yatırımlarına yön verilerek, turizme konu olan maliyetlerin azaltılması ve turistik talebin arttırılması sağlanabilecektir. 


\section{Araştırmanın Evren ve Örneklemi}

Araştırmanın evrenini Giresun ilinde turizm alanında yönetici olan kişiler oluşturmaktadır. Bu kapsamda, İl Kültür ve Turizm Müdürlüğü’nden 2 yönetici, Giresun Belediyesi’nden 1 yönetici, seyahat acentesi 2 yönetici, otel genel müdürü 3 yönetici, turizm alanında çalışmakta olan sivil toplum kuruluşlarından 1 yönetici ve turizm alanında doktora dereceli 1 akademisyen oluşturmaktadır. Toplam 10 yönetici araştırmanın örneklemini oluşturmaktadır.

Araştırma örnekleminin evrenini destekleme konusunda, çalışmada uygulanan AHP yöntemi diğer yöntemlerden farklılık göstermektedir. Çok kriterli karar verme yöntemleri içerisinde bulunan AHP yönteminde, örneklemin evreni temsil etmesi için alanında uzman bir kişi bile yeterli olarak kabul edilmektedir. Uzman görüşlerinin bilimsel amaçlı olarak kullanılmasında, çok kriterli karar verme yöntemlerinde tek uzmanın fikir ve tecrübeleri yeterli olarak görülmektedir (Erdal ve Korucuk, 2018: 103; Korucuk, 2021: 249). Bu kapsamda, çok kriterli karar verme yöntemlerinin uygulanmasındaki durum nedeni ile araştırma örneklemi, araştırma evrenini temsil edecek nitelikte olarak değerlendirilmektedir.

\section{Araştırmanın Veri Toplama Yöntemi ve Sınırlılıkları}

Çalışma ilk olarak anketlerin hazırlanması ile başlatılmıştır. Söz konusu kriterler kendi arasında ikili karşılaştırmalar yapılarak Analitik Hiyerarşi Süreci ile analiz edilmiştir. Kriterlerin birbiri arasındaki önem dereceleri belirlenmiş olup, bir sonraki aşamada anketler turizm yöneticileriyle yüz yüze görüşme yoluyla yapılmıştır.

Araştırmanın uygulama sürecinde, Türkiye'deki mevcut Corona virüs salgını nedeni ile bazı yöneticilerin esnek çalışma koşullarında çalışması ve bazı yöneticilerin de yüz yüze görüşmeye sıcak bakmaması, araştırmanın sınırlılığını oluşturmaktadır.

\section{Araştırmanın Geçerliliği ve Güvenirliliği}

Araştırmada kullanılan kriterlerin geçerlilik ve güvenilirliği için daha önceden yapılmış çalışmalardan elde edilmiştir. Bayat (2010:97), tarafından Iğdır ilinde yerel halkın algısına yönelik olarak ekoturizm alanında yapılmış olan çalışmanın güvenirliliği \%95; Bunruamkaew and Murayama (2011:273), tarafından otel yöneticilerine ekoturizm değerlendirilmesinin yapıldığı çalışmada güvenirlilik \%89 ve Kavak (2015:153), tarafindan yapılan Edremit ekoturizmine yönelik olarak çalışmasında ise güvenirlilik \%91 olarak belirtilmektedir. Araştırma kriterleri, daha önce geçerliliği ve güvenirliliği onaylanmış yukarıda belirtilen ekoturizm çalışmalarından elde edilmiştir. Araştırmada, Giresun ili için oluşturulan 7 (yedi) kriter belirlenmiştir. Bu kriterler aşağıdaki Tablo-1'de verilmektedir. 
Tablo 1: AHP ölçeği temel kriterler tablosu

\begin{tabular}{c}
\hline Temel Kriterler \\
\hline Ulaşım \\
\hline Fiyat \\
\hline Doğal Şartlar \\
\hline İklim \\
\hline Yayla Turizmi \\
\hline Konaklama tesisleri \\
\hline Güvenlik \\
\hline
\end{tabular}

Araştırma için kullanılan ekoturizm değerlendirme kriterleri, ülkelere ve bölgelere göre değişim göstermektedir. Temel olarak, yukarıda belirtilen ulaşım, fiyat, doğal şartlar, iklim, yayla turizmi, konaklama tesisleri ve güvenlik kriterleri dışında, farklı çalışmalarda çevresel şartlar, doğal güzellikler, rafting, trekking, dă̆ tırmanışı, bisiklet rotaları gibi farklı kriterlerin de kullanıldığı görülmektedir.

\section{Araştırmanın Analizi}

Araştırmada katılımcıların demografik bilgilerinin analizinde SPSS tekniği, kriterlerin değerlendirilmesinde ise AHP yöntemi kullanılmıştır. Bu kapsamda, AHP yönteminin detaylı olarak incelenmesi, çalışmanın temelini oluşturduğundan, genel olarak AHP yöntemini açıklamak uygun olacaktır.

\section{Analitik Hiyerarşi Prosesi (AHP)}

AHP, çok kriterli karar vermek, planlama, kaynak dağıtımı ve anlaşmazlıkların çözülmesinde kullanılan yöntemdir. Başka bir ifadeyle, genel bir ölçme teorisidir. (Saaty ve Vargas, 2000: 2). Çok kriterli karar verme yöntemlerinden biri olan Analitik Hiyerarşi Süreci, ilk olarak 1968 y1lında Myres ve Alpert tarafından ortaya atılmış ve sonrasında 1977 yılında Saaty tarafından bir model geliştirilerek karmaşık karar problemlerinin çözümünde kullanılabilir hale getirilmiştir (Girginer, 2008: 135). AHP, bir konu hakkında fikir sahibi veya uzman kişiler tarafından kendi görüşlerini ortaya koyarak ortak bir kararın oluşturulmasındaki araçlardan biridir yani oran ölçeklerini ikili karşılaştırmalardan türetme yöntemidir (Önder ve Önder, 2015: 21).

$\mathrm{Bu}$ yöntem, karmaşık problemlerin çözümünde alanında uzman kişilere uygulanmaktadır. $\mathrm{Bu}$ uygulama ekonomi, planlama, turizm, sağlık, pazarlama, işletme, muhasebe, eğitim, mimarlık, mühendislik gibi birçok farklı alanda kullanılmaktadır. Drumm and Moore (2002)'ye göre ekoturizm yapılacak alanın yönetim kadrosu, kamu kurum temsilcileri, uzmanlar ve bilim insanları, yerel temsilciler, seyahat acenteleri, tur operatörleri, kar amacı gütmeyen sivil toplum kuruluşları planlama sürecine kat1lmas1 gerekmektedir (Y1lmaz ve Surat, 2015, 166-167). 
AHP yönteminin aşamaları aşağıda adımlar halinde sunulmaktadır (Saaty, 1994: 21-24; Saaty, 2008: 85; Başkaya ve Akar, 2005: 275; Vatansever, 2013: 239):

1.Adım: Hiyerarşik Yapı Oluşturulması: Çok kriterli karar probleminin çözümü için hiyerarşik yapısını oluşturulması gerekmektedir. Bu yapı da problem, problemi etkileyen faktörler ve alt faktörlerle problemin çözümü için kriterler önemlidir. AHP'de yapı için minimum 3 seviyeden oluşur. En üstteki seviyede karar probleminin amacı bulunmaktadır. Orta seviyede, karar problemini etkileyen kriterler bulunur. En alt kademedeki seviyede ise karar alternatifleri yer almaktadır.

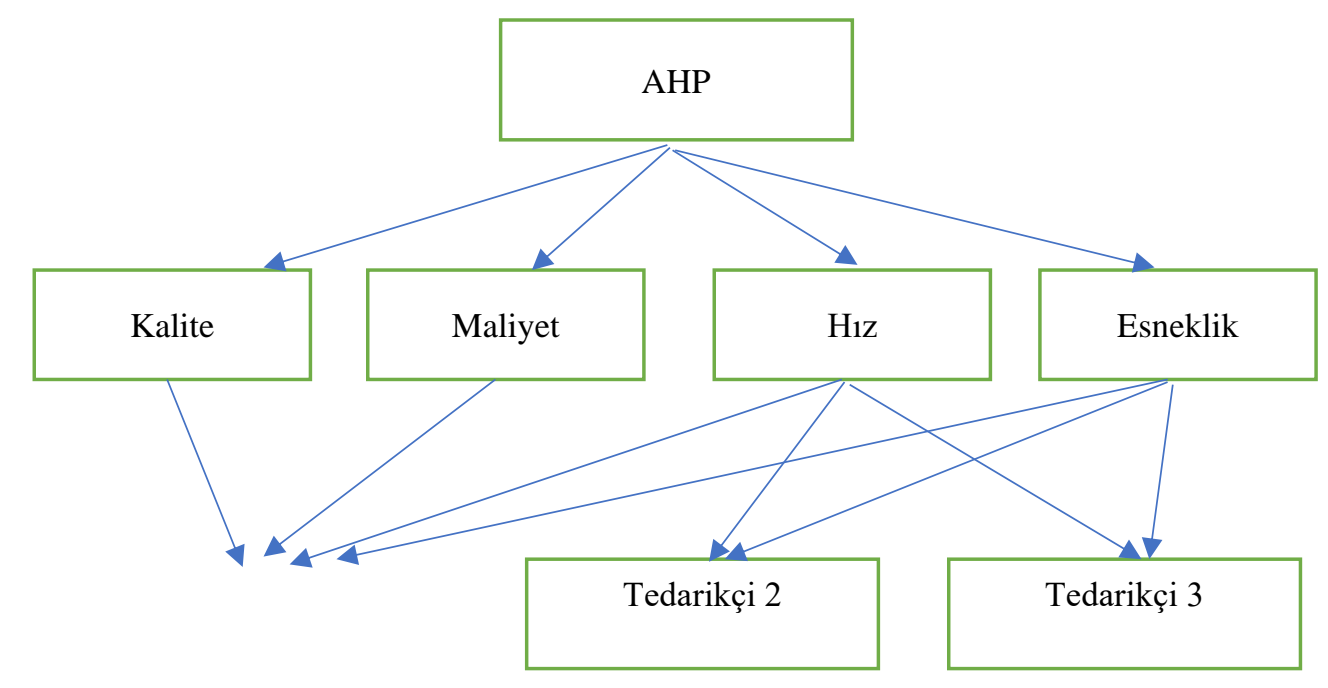

Şekil 1: AHP'de kullanılan temel hiyerarşik yapı (Vatansever, 2013: 238).

2.Adım: Karşılaştırmalara Dayalı Karar Matrisinin Oluşturulması:

Saaty ve Niemira (2006), tarafindan geliştirilen 1-9 arasındaki önem ölçeğinde kullanılan kriterler, diğer seçeneklerle karşılaştırılarak karar matrisleri oluşturulmaktadır.

Tablo 2: AHP ölçeği önem dereceleri tablosu

\begin{tabular}{|c|c|c|}
\hline $\begin{array}{c}\text { Önem } \\
\text { Derecesi }\end{array}$ & Tanım & Açıklama \\
\hline 1 & Eşit derecede önemli & Her iki faktör eşit derece önemli \\
\hline 3 & Orta derece önemli & $\begin{array}{c}\text { Düşüncelere göre bir faktör diğerine göre çok daha az } \\
\text { önemli }\end{array}$ \\
\hline 5 & Kuvvetli derecede önemli & Bir faktör bir diğerinden kuvvetli olarak daha önemli \\
\hline 7 & Yüksek derecede önemli & $\begin{array}{c}\text { Bir faktör diğerine göre çok yüksek derecede daha } \\
\text { önemli }\end{array}$ \\
\hline 9 & Mutlak derecede önemli & Bir faktör diğerine göre çok yüksek derecede önemli \\
\hline $2,4,4,8$ & Ara değerler & Diğer derecelerin ara değerleridir \\
\hline
\end{tabular}

Kaynak: Saaty ve Niemira, 2006:3. 
3.Adım Kriter ağırlıklarının hesaplanması: Öncelikle ikili karşılaştırmalara dayalı olarak oluşturulan karar matrisi normalize edilerek B normalize karar matrisi oluşturulur. Normalizasyon işleminde aşağıdaki formül uygulanmaktadır.

Denklem 1

$$
b_{i j}=\frac{a_{i j}}{\sum_{i=1}^{n} a_{i j}}
$$

Yukarıdaki formül ile elde edilen B normalize karar matrisinin satır elemanlarının aritmetik ortalaması alınarak W ağılık vektörüne ulaşılmaktadır.

Denklem 2

$$
W=\frac{\sum_{i=1}^{n} b_{i j}}{n}
$$

4.Adım Tutarlılık Testi: AHP'nin son ve en önemli adımıdır. İkili karşılaştırılmasının belirlenmesinde kararın uyumluluk göstermesi tutarlılığın ölçüsüdür. ikili karşılaştırılmasının karar vericilerin tutarlı ve gerçekçi olduklarını göstermektedir. Uzman görüşlerinin tercih edilmesi tutarlılığın güvenilirliğini artırmaktadır. Tutarlılığın test edilmesiyle ilgili parametreler; tutarlılık indeksi (Consistency Index-CI) ve tutarlılık oranıdır (Consistency Ratio-CR). Bu parametrelerin hesaplanmasında aşağıdaki formül uygulanmaktadır

Denklem 3

$$
C I=\frac{\lambda_{\max }-n}{n-1}
$$

Denklem 4

$$
C R=\frac{C I}{R I}
$$

$\lambda_{\max }$ değerinin hesaplanmasında, öncelikle ikili karşılaştırmalara dayalı karar matrisi ile ağırlık vektörü çarpılarak bir sütun vektörü hazırlanır. Elde edilen sütun vektörü elemanları karşılıklı olarak W ağırlık vektörü elemanlarına bölünür ve elde edilen değerlerin aritmetik ortalaması alınarak $\lambda_{\max }$ değerine ulaşılır. 
$\left(\lambda_{\max }-\mathrm{n}\right) /(\mathrm{n}-1)$ formülüyle bulunan CI değeri, $a_{i j}$ lerin tahmininde meydana gelen hataların varyansıdır.

$\mathrm{CR}$ ise, CI ile ortalama rasgele tutarlılık indeksi (Random Index-RI) tablosunda, kriter sayısına göre verilen uygun sayıyla karşılaştırılması sonucu elde edilir.

Tablo 3: Rastgele değer indeksi (R.İ)

\begin{tabular}{ccccccccccc}
\hline $\mathrm{n}$ & 1 & 2 & 3 & 4 & 5 & 6 & 7 & 8 & 9 & 10 \\
\hline $\mathrm{RI}$ & 0 & 0 & 0,58 & 0,9 & 1,12 & 1,24 & 1,32 & 1,41 & 1,45 & 1,49 \\
\hline
\end{tabular}

RI değerleri, $1 / 9,1 / 8, \ldots ., 1, \ldots 8,9$ skalası kullanılarak örnekten türetilen rassal sayılardır. Hesaplama sonucunda elde edilen CR değerinin 0,10'dan küçük olması gerekmektedir. 0,10 değerinden büyük olması durumunda ikili karşılaştırma matrislerinde hesaplama hatası olduğunu ya da ankete katılanların tutarsız cevaplara işaretlediklerinin göstergesidir.

\section{Araştırmanın Bulguları}

Araştırmada ilk olarak SPSS tekniği ile katılımcılara ait demografik sonuçlar ortaya konulmaktadır. Bu sonuçlar, Tablo-4'te verilmektedir.

Tablo 4: Demografik özelliklere ilişkin frekans dağılımı

\begin{tabular}{|c|c|c|c|}
\hline \multicolumn{2}{|l|}{ Değişken (n: 10) } & \multicolumn{2}{|c|}{ Katılımc1 } \\
\hline \multirow{2}{*}{ Cinsiyet } & Kadın & 2 & 20 \\
\hline & Erkek & 8 & 80 \\
\hline \multirow{5}{*}{ Çalışma Süresi } & $1-5 \mathrm{y} 11$ & 3 & 30 \\
\hline & $5-10 \mathrm{y} 11$ & 3 & 30 \\
\hline & $10-15$ y1l & 2 & 20 \\
\hline & $15-20$ y1l & & \\
\hline & 20 ve üstü & 2 & 20 \\
\hline \multirow{5}{*}{ Görevi } & Seyahat acente Müdür & 2 & 20 \\
\hline & Otel Müdür- Genel Müdür & 3 & 30 \\
\hline & Kamu Turizm Yönetici & 3 & 30 \\
\hline & Akademisyen & 1 & 10 \\
\hline & Diğer Yöneticiler & 1 & 10 \\
\hline \multirow{4}{*}{ Eğitim durumu } & Temel Lise & 1 & 10 \\
\hline & Lisans Diğer Bölümler & 1 & 10 \\
\hline & Lisans Turizm Bölümleri & 1 & 10 \\
\hline & $\begin{array}{l}\text { Yüksek Lisans Diğer } \\
\text { Bölümler }\end{array}$ & 4 & 40 \\
\hline
\end{tabular}




\begin{tabular}{c|l|l|l} 
& $\begin{array}{l}\text { Alan dişı Yüksek Lisans } \\
\text { devam ediyor }\end{array}$ & 2 & 20 \\
\cline { 2 - 4 } & Doktora Turizm & 1 & 10 \\
\hline \multirow{2}{*}{$\begin{array}{c}\text { Ekoturizmle ile ilgili bir Otelde Çalışma } \\
\text { Durumu }\end{array}$} & Evet & 4 & 40 \\
\cline { 2 - 4 } & Hayır & 6 & 60 \\
\hline
\end{tabular}

Tablo-4'e göre katılımcı yöneticilerin \%80 gibi önemli bir kısmını erkek yöneticiler oluşturmaktadır. Çalışma sürelerinde $\% 80$ oranında 15 yıl ve altı sürede çalışan yöneticiler oluşturmaktadır. Kamu turizm yöneticisi 3 kişi, seyahat acentesi 2 yönetici, otel müdür veya genel müdürü 3 yönetici, turizm alanında çalışmakta olan sivil toplum kuruluşlarından 1 yönetici ve turizm alanında doktora dereceli 1 akademisyen katılımcı bulunmaktadır. Yöneticilerin, akademisyen katılımcı hariç, \%80 gibi önemli bir bölümü turizm dışı alanlarda eğitim aldıklarını belirtmektedir. Ekoturizm alanında çalışmalarına ilişkin soruya verilen cevapta ise katılımcı yöneticilerin \%60'nın ekoturizm destinasyonlarında çalışmadığı sonucu elde edilmiştir.

AHP yöntemi kullanılarak uygulanan ankete ait veriler doğrultusunda, Giresun ili turizm yöneticilerinin ekoturizm algılamalarına yönelik olarak kriter seçimleri elde edilmiştir. Ardından, seçim kriterleri sonuçlarına yönelik olarak ikili karşılaştırmaları yapılmıştır. Elde edilen verilerin geometrik ortalaması alınarak ikili karar matrisleri oluşturulmuştur. İkili karşılaştırmalar matrisi sonuçları Tablo5 'te gösterilmektedir.

Tablo 5: İkili karşılaştırmalar matrisi

\begin{tabular}{lccccccc}
\hline & $\begin{array}{l}\text { Doğal } \\
\text { Şartlar }\end{array}$ & Ulaşım & Íklim & Güvenlik & $\begin{array}{c}\text { Yayla } \\
\text { Turizmi }\end{array}$ & $\begin{array}{c}\text { Konaklama } \\
\text { Tesisleri }\end{array}$ & Fiyat \\
\hline $\begin{array}{l}\text { Doğal } \\
\text { Şartlar }\end{array}$ & 1,0000 & 0,7496 & 0,9368 & 0,4438 & 0,8548 & 1,0414 & 0,6762 \\
\hline Ulaşım & 1,3341 & 1,0000 & 3,2073 & 0,3925 & 1,6141 & 0,8960 & 0,7750 \\
\hline İklim & 1,0674 & 0,3118 & 1,0000 & 0,3500 & 3,4740 & 1,6186 & 0,5330 \\
\hline Güvenlik & 2,2533 & 2,5477 & 2,8574 & 1,0000 & 1,3195 & 3,3754 & 2,7130 \\
\hline $\begin{array}{l}\text { Yayla } \\
\text { Turizmi }\end{array}$ & 1,1698 & 0,6196 & 0,2879 & 0,7579 & 1,0000 & 0,7943 & 1,1962 \\
\hline $\begin{array}{l}\text { Konaklama } \\
\text { Evleri }\end{array}$ & 0,9603 & 1,1161 & 0,6178 & 0,2963 & 1,2589 & 1,0000 & 0,7442 \\
\hline Fiyat & 1,4788 & 1,2904 & 1,8760 & 0,3686 & 0,8360 & 1,3438 & 1,0000 \\
\hline
\end{tabular}

İkili karşılaştırmalar matrisi oluşturulduktan sonra, AHP yöntemi adımları gereği, Tablo-5’ten elde edilen verilerle kriterlerin ağırlıklandırılması işlemi yapılmıştır. Bu işlemlerin sonucu Tablo-6' da verilmektedir. 
Turizm Yöneticilerinin Ekoturizm Algısının AHP Yöntemi ile Belirlenmesi: Giresun İli Örneği

Tablo 6: Kriterlere göre ağırlıklandırma sonuçları

\begin{tabular}{lcccccccc}
\hline & $\begin{array}{l}\text { Doğal } \\
\text { Şartlar }\end{array}$ & Ulaşım & İklim & Güvenlik & $\begin{array}{l}\text { Yayla } \\
\text { Turizmi }\end{array}$ & $\begin{array}{l}\text { Konaklama } \\
\text { Tesisleri }\end{array}$ & Fiyat & $\begin{array}{c}\text { Önem } \\
\text { Düzeyi }\end{array}$ \\
\hline $\begin{array}{l}\text { Doğal } \\
\text { Şartlar }\end{array}$ & 0,1079 & 0,0982 & 0,0869 & 0,1230 & 0,0825 & 0,1034 & 0,0885 & 0,0986 \\
\hline Ulaşım & 0,1440 & 0,1310 & 0,2974 & 0,1088 & 0,1558 & 0,0890 & 0,1015 & 0,1468 \\
\hline İklim & 0,1152 & 0,0408 & 0,0927 & 0,0970 & 0,3354 & 0,1607 & 0,0698 & 0,1302 \\
\hline Güvenlik & 0,2432 & 0,3337 & 0,2650 & 0,2771 & 0,1274 & 0,3352 & 0,3552 & 0,2767 \\
\hline $\begin{array}{l}\text { Yayla } \\
\text { Turizmi }\end{array}$ & 0,1263 & 0,0811 & 0,0267 & 0,2100 & 0,0966 & 0,0789 & 0,1566 & 0,1109 \\
\hline $\begin{array}{l}\text { Konaklama } \\
\text { Tesisleri }\end{array}$ & 0,1037 & 0,1462 & 0,0573 & 0,0821 & 0,1216 & 0,0993 & 0,0974 & 0,1011 \\
\hline Fiyat & 0,1596 & 0,1690 & 0,1740 & 0,1021 & 0,0807 & 0,1335 & 0,1309 & 0,1357 \\
\hline
\end{tabular}

Not: $\mathrm{CR}=0,079103$

CR değeri 0,1 'den küçük $(0,079103)$ çıktığ 1 için ankete verilen cevapların güvenilir olduğu sonucu ortaya çıkmaktadır. Araştırmanın CR değerinin 0,1'den küçük çıkması ankete verilen cevapların da anlamlı olduğu anlamı taşımaktadır. CR değerinin 0,10'den büyük çıkması ya AHP yöntemindeki bir hesaplama hatasını ya da ankete katılanların tutarsız cevaplar verdiğini ifade etmektedir (Saaty, 2008: $82)$.

Kriterlerin ağırlıklandırılması adımından sonra AHP ölçeğine uygun olarak kriterlerin önem derecesine göre sıralanması adımı yapılmıştır. Bu adıma yönelik olarak veriler Tablo-7'de verilmektedir.

Tablo 7: AHP ölçeği temel kriterlerin önem derecesi sıralaması

\begin{tabular}{l|l|l}
\hline Kriter & Önem Derecesi Sıralaması & \\
\hline 1 & Güvenlik & 0,2767 \\
\hline 2 & Ulaşım & 0,1468 \\
\hline 3 & Fiyat & 0,1357 \\
\hline 4 & İklim & 0,1302 \\
\hline 5 & Yayla Turizmi & 0,1109 \\
\hline 6 & Konaklama Tesisleri & 0,1011 \\
\hline 7 & Doğal Şartlar & 0,0986 \\
\hline
\end{tabular}


Önem düzeyi matrisine göre, Güvenlik kriteri $(0,2767)$ en önemli kriter olarak belirlenmiştir. Daha sonra sırasıyla, Ulaşım $(0,1468)$, Fiyat $(0,1357)$, İklim $(0,1302)$, Yayla turizmi $(0,1109)$, Konaklama tesisleri $(0,1011)$ ve Doğal Şartlar $(0,0986)$ kriterleri sonucu ortaya çıkmıştır.

\section{Sonuç ve Öneriler}

Turizm sektörünün gelişmesi ve modern anlamda değişime uğraması son otuz yılla birlikte hızlanmıştır. Senelik izin kavramı ve daha düzenli gelire sahip olan kişilerin turistik faaliyetlere katılımının, ulaşım firsatlarının artmasıyla birlikte, turizmin lüks olmaktan çıkarak temel bir ihtiyaç halini almasına neden olmuştur. Toplumların turizmden elde ettikleri gelirlerinin artması, doğaya ve çevresel unsurlara karşı bilinç düzeyinin gelişmesi ile turizm türlerinde de değişimler olmuştur. Özellikle, son iki yıldır yaşanan virüs salgını ile doğaya yönelik turistik talepte daha fazla artış yaşanmıştır. İnsanların kalabalık ortamlar yerine hem doğada farklı turizm türlerini tecrübe etme istekleri hem de kalabalık şehirlerden uzaklaşarak dinlenme arzuları, turizmin doğa tabanlı türlerinin ortaya çıkmasında rol oynamıştır.

Bu kapsamda, özellikle Türkiye gibi doğal alanlarının çok olduğu ülkeler, ekoturizm alanında yatırımlar yapmaktadır. Türkiye'de ekoturizm kapsamında adı geçen en önemli bölge Doğu Karadeniz Bölgesi olarak görülmektedir. Yaylalarının fazlalığı ve el değmemiş doğal alanları ile önemli bir ekoturizm destinasyonu olarak belirtilmektedir. Giresun ili ekoturizm kapsamında yaylaları, milli parkları, sit alanları ve doğal manzaraları olan birçok destinasyona sahiptir. Giresun ilinin ekoturizme etki eden kriterlerinin, ildeki turizm yöneticileri tarafından ele alınması, önemli bir bilgi kaynağıdır.

Çalışma ile benzer olan, Bunruamkaewa ve Murayama (2011) yılında yapmış olduğu araştırmada, araştırmanın evreni farklılık gösterse de, ekoturizm kriterleri benzer olarak belirtilmektedir. Bu kapsamda, araştırmada "doğal şartlar" kriteri en önemli ekoturizm kriteri olarak ifade edilmektedir. Mevcut çalışmada ise "güvenlik" kriteri en önemli kriter olarak belirlenmiştir. Bu durum, destinasyonların farklılığına ve araştırma evrenine göre sonuçların değişebileceğini ortaya koymaktadır.

Çalışmada, Giresun ili turizm yöneticisi ve akademisyenlerden oluşan hedef kitleye anket uygulanmış, bu anketten elde edilen demografik bilgilerde en önemli sonucu, yöneticilerin \%80 gibi önemli bir oranının turizm eğitimi almamış kişilerden oluştuğudur. Turizm eğitimi, günümüz koşullarında Türkiye'de birçok ilde lise, önlisans, lisans, yüksek lisans ve doktora derecelerinde yaygın olarak verilmektedir. Gelecekte turizm ile ilgilenen yöneticilerin turizm eğitimi almış olmalarının, turizme bakış açısı ve vizyon açısından önemli olacağ düşünülmektedir. Mevcut sistemde, turizm eğitimi alan yönetici sayısının azlığı, geçmişte turizm eğitiminin günümüzdeki kadar yaygın olmaması ile ilişkilendirilebilir. Demografik sonuçlardan elde edilen diğer bir çarpıcı bilgi ise kadın yöneticilerin oranının \%20 olmasıdır. Erkek yöneticilerin sayısının kadınlara oranla çok daha fazla olduğu görülmektedir. Sektörün gelecekte kadın yöneticiler içinde önemli bir istihdam alanı olması beklenmektedir. 
AHP yöntemi sonucunda elde edilen verilerde, Giresun ili turizm yöneticileri açısından "güvenlik" en önemli ekoturizm kriteri olarak belirtilmektedir. Bu durum, bölgenin ekoturizm faaliyetlerindeki genel güvenlik şartlarının arttırılması gerektiği sonucunu ortaya çıkarmaktadır. Bununla birlikte diğer en önemli sonuç ise, "ulaşım" kriteridir. Giresun ili ekoturizm alanlarına turistlerin daha güvenli ve kolay ulaşımı önemli bir altyapı sorunu olarak görülmektedir. Turizm açısından elverişli destinasyonlara ulaşımın kolay olarak sağlanması hem tanıtımının daha kolay yapılmasında etkili olacaktır hem de turistik talebin arttırılmasında önemli bir rol oynayacaktır. Coğrafi yapı bakımından uygun olmayan şartlar, iklim koşulları ve ulaşımın bir arada koordineli şekilde çözüme kavuşturulması, Giresun ekoturizm destinasyonlarına olan talebi doğrudan etkileyecek ve de yöre halkının turizmden elde ettikleri gelirleri yükseltecektir.

Çalışma sonucunda diğer önemli ekoturizm kriterleri ise fiyat, iklim, yayla turizmi, konaklama tesisleri ve doğal şartlar olarak belirlenmiştir. Bu sonuçlara göre, Giresun ili turizm yöneticileri açısından ilin doğal şartları normal olarak kabul edilmektedir. Doğal manzara ve alanların Giresun açısından çok zengin olması, böyle bir algılamaya yol açmış olabilir. Ayrıca, ekoturizm birçok turizm türünü içinde barındırmasına rağmen, yayla turizmi ekoturizmin temel kriterleri arasında gösterilmektedir. Bu sonucun, Giresun ilinin yaylalar açısından zengin olması ile doğrudan ilişkili olduğu düşünülmektedir.

Giresun'da faaliyet gösteren turizm yöneticilerinin ekoturizm algılamalarının tespitine yönelik olarak elde edilen bulgular sonrasında, aşağıda belirtilen öneriler geliştirilmiş ve maddeler halinde ifade edilmiştir:

Ekoturizm konusunda başta bölgedeki turizm işletmeleri olmak üzere ilgili bütün kuruluşlarda çalışanların eğitim programlarından faydalandırılarak, ekoturizm konusunda bilinç düzeyi arttırılmalıdır.

Bölgede ulaşım araçlarında ve konaklama tesislerinde iyileştirmeler yapılarak, uzun vadeli planlamalar yapılmalıdır.

Ekoturizm faaliyetlerinin muhataplarından olan yerel halk belirli dönemlerde gerekli eğitim programları ile desteklenerek karşı karşıya kalacakları durum hakkında bilgi sahibi olmaları sağlanmalıdır.

Bölgeye yapılacak turizm yatırımlarının bilinçsiz ve plansız yapılmasının önüne geçilerek, ekoturizm göz önüne alınarak çevresel ve kültürel sürdürülebilirlik temelli olarak planlanmasına yönelik denetim ve de imkanlar sağlanmalıdır.

Ekoturizm destinasyonları için ulusal ölçekte bilinçlendirme faaliyetleri kapsamında etkinlikler, kısa filmler, konferans ve kongreler, yarışma ve festivaller düzenlenerek ekoturizm faaliyetlerinin nasıl olması ve nasıl olmaması gerektiği anlatılmalıdır. 
Destinasyon yönetiminin bölgede etkin bir şekilde yapılarak, ekoturizme dair kararların yerel halk ile işbirliği içerisinde alınmasına yönelik katılımı sağlanmalıdır.

Ekoturizm faaliyetlerinin bölgede gelişmesinin, yatırımları ve iş fırsatlarını beraberinde getireceği göz önüne alınarak, turizm eğitimleri arttırılmalı ve nitelikli personel yetiştirilmelidir.

Ekoturizm alanları yeniden gözden geçirilerek, doğal, çevresel ve kültürel sürdürülebilirliğe engel teşkil edebilecek sorunlar ortaya konmalı, uzun süreli kapsamlı planlamalar yapılmalıdır.

Giresun'un ekoturizm faaliyetleri bakımından bölgede yer alan diğer illere nazaran daha yeni yapılanıyor olmasının avantajı mutlaka kullanılarak, gerek turizm işletmeleri gerekse diğer paydaşların desteklenmesi ile ekoturizm konusunda çalışmaların arttırılması gerekmektedir.

Yazar Katkıları: Bu çalışmada yazarların çalışmaya katkısı tamdır. Her iki yazar çalışmanın bütününde iş birliği ve ortak çalışmayı esas almıştır. Çalışmada yer alan literatür özeti, alan araştırması ve verilerin analizi kısımları yazarların ortak çabasıyla tamamlanmıştır.

Çıkar Beyanı : Bu çalışmada yazarlar arasında herhangi bir çıkar çatışması bulunmamaktadır.

\section{Kaynaklar}

Ahmadova, S ve Akova, O. (2016). Türkiye'de organik ekoturizm çiftlikleri üzerine bir araştırma. Karabük Üniversitesi Sosyal Bilimler Enstitüsü Dergisi, 6 (1), 14-29.

Akbulut, G., Atmış, E. ve Günşen, H.B. (2015). Farklı ilgi gruplarının milli park algıları üzerine bir değerlendirme: Küre dağları milli parkı örneği, Kastamonu Üniversitesi Orman Fakültesi Dergisi, 15 (1), 133-145.

Akyurt, H. (2019). Ekoturizm: Türkiye'deki gelişimi ve mevcut durumu. Sosyal, Beşeri ve İdari Bilimler Alanında Araştırma ve Değerlendirmeler, Cilt 2, Ankara: Gece Akademi.

Ayotte, L.A. (2009). Ecotourism as a form of sustainable development in south africa,. Queen's University Kingston, Ontario, Canada.

Başkaya, Z. ve Akar, C. (2005). Üretim alternatifi seçiminde analitik hiyerarşi süreci: Tekstil işletmesi örneği, Anadolu Üniversitesi Sosyal Bilimler Dergisi, 5 (1), 273-286.

Bayat, G. (2010). Turizmin yerel halk tarafından algılanması: Iğdır halkı üzerine bir araştırma., Kafkas Üniversitesi Sosyal Bilmeler Enstitüsü, Yüksek Lisans Tezi, Kars.

Bhattacharya, D. Chowdhury, B. and Sarkar, R. (2011). Irresponsıble ecotourısm practıces flankıng the best national park inındia: a multivariate analysis. 2nd International Conference On Business and Economic Research Proceeding, 1901-1928.

Bunruamkaew, K. and Murayama, Y. (2011). Site suitability evaluation for ecotourism using GIS \& AHS: A case study of Surat Thani province. Thailand, Social and Behavioral Sciences, 21, 269-278.

Butarbutar, R. and Soemarno. (2013). Environmental effects of ecotourism in indonesia. Journal of Indonesian Tourismand Development Studies, 3.1(3), 97-107.

Chan, E.S.W. (2013). Managing green marketing: Hong Kong hotel managers' perspective. International Journal of Hospitality Management, 34, 442- 461.

Das, M. and Chatterjee, B. (2015). Ecotourism: a panacea or a predicament, Tourism Management Perspectives, 14, 3-16. 
Doğan, M. (2011). Mengen ve çevresinin ekoturizm potansiyelinin değerlendirilmesi. İstanbul Üniversitesi Coğrafya Dergisi, 1(22), 14-26.

Doğaner, S. (2001). Türkiye turizm coğrafyası. Çantaya Kitabevi: İstanbul.

Erdal, H. ve Korucuk, S. (2018). İmalat işletmelerinde yeni ürün geliştirme kriterleri: Karadeniz Bölgesi örneği. Trakya Üniversitesi Sosyal Bilimler Dergisi, 20(1), 99-112.

Erdoğan, N. (2003). Çevre ve (eko)turizm. Ankara: Genel Yayın ve Dağıtım.

Farrell, B.H., and Runyan D. (1991). Ecology and tourism. Annals of Tourism Research. 18, 26- 40.

Girginer, N. (2008). Ticari kredi taleplerinin değerlendirmesine çok kriterli yaklaşım: özel ve devlet bankası karşılaştırması. Muhasebe ve Finansman Dergisi, 37, 132-141.

Gündüz, B. ve Dönmez, Y. (2018). Üniversite Çalışanlarının Ekoturizm Algısı. Bartın Orman Fakültesi Dergisi, 20(2), 152-162.

Ilgaz, B. ve Kozak, M. (2019). Turistlerin destinasyon seçim kriterlerinin değerlendirilmesi: AHS ve TOPSIS uygulamas1, Emir, O. (Editör.) 20. Ulusal- 4. Uluslararası Turizm Kongresi, Eskişehir. Anadolu Üniversitesi, 496-503.

Işık, C. ve Çalkın, Ö. (2016). Yerel Halkın Turizm Algısı: Tra2 Bölgesi Analizi. IUJEAS, 1(2), 19-48.

Kavak, M. (2015). Edremit körfezi kuzey kıyılarında yerel halkın ekoturizme yönelik bilinç algısı ve tutumları. Yüksek Lisans Tezi, Çanakkale Onsekiz Mart Üniversitesi Ĕgitim Bilimleri Enstitüsü, Çanakkale.

Kaypak, Ş. (2012). Ekolojik turizm ve sürdürülebilir kırsal kalkınma, KMÜ Sosyal ve Ekonomik Araştırmalar Dergisi, 14(22), 11-29.

Korucuk, S. (2021). Ordu ve Giresun İllerinde Kentsel Lojistik Performans Unsurlarına Yönelik Karşılaştırmalı Bir Analiz. Dicle Üniversitesi Sosyal Bilimler Enstitüsü Dergisi, 13(26), 141155 .

Kuter, N. ve Ünal, H.E. (2009). Sürdürülebilirlik kapsamında ekoturizmin çevresel, ekonomik ve sosyokültürel etkileri. Kastamonu Üniversitesi, Orman Fakültesi Dergisi, 9 (2), 146-156.

Önder, G. ve Önder, E. (2015). Analitik hiyerarşi süreci. (Editörler), Yıldırım, B.; Önder, E. Çok Kriterli Karar Verme Yöntemleri, Dora Yayıncılık, 21-74.

Saaty T.L. (1994). How to make a decision: the analytic hierarchy process, Interfaces, 24(6), 19-43.

Saaty, T.L. and Vargas, L.G. (2000). Models, methods, concepts and applications of the analytic hierarchy process. Boston: Kluwer Academic Publishers.

Saaty, T.L. ve Niemira, M.P. (2006). A framework for making a better decision, Research Review, 13(1), $1-4$.

Saaty, T.L. (2008). Decision making witht heanalytic hierarchy process, International Journal of Services Sciences, 1(1), 83-98.

Tisdell, C.A. (2003). Ecotourism, economics, and the environment: observations from china. Journal of Travel Research, 34, 91-99.

Ünlü, H. ve Erbaş, A. (2021). Trabzon'da otel yöneticilerinin eko turizm hakkındaki görüşleri. $A H B V \ddot{U}$ Turizm Fakültesi Dergisi, 24(1), 142-160.

Vatansever, K. (2013). Kamu hastanelerinde mal alım kararlarının bulanık AHP yöntemiyle değerlendirilmesi ve Gediz devlet hastanesi uygulaması. Süleyman Demirel Üniversitesi İktisadi ve İdari Bilimler Fakültesi Dergisi, 18(3), 225-244.

Yılmaz, H. ve Surat, H. (2015). Analitik hiyerarşi süreci kullanılarak en uygun ekoturizm etkinliğinin belirlenmesi. Turkish Journal of Forestry, 16(2), 164-176. 
Yücel, C. (2002). Turizmde yükselen değer: ekoturizm. TÜRSAB Dergisi, 219, 4-9.

Wood, M.E. (2002). Ecotourism: principles, practises \& policiesfor sustainability, United Nations Environment Programme. United Nations Publication, France. 